\title{
Margaret Fuller and the New York Christian Inquirer
}

\section{Holly Mathews}

Dr. James Duban (Faculty Editor)

Margaret Fuller, a member of the New England transcendentalist circle and advocate for women's rights, successfully appealed, beyond a host of audiences, to American Unitarians in celebrating the potential of human nature. I suggest that a heretofore overlooked series of nineteenthcentury reviews in the New York Christian Inquirer allows twenty-first-century readers better to appreciate Fuller's contribution to both the politics of the Unitarian movement and that sect's outlooks on women in society. In Woman in the Nineteenth Century, Fuller urges that the female sex be allowed to work in whichever profession is best suited for contribution and enhancement rather than in a few customarily acceptable positions, even as some writers of the time believed mainly in a woman's right to maintain a household rather than assume any other responsibility. Fuller thereby appeals directly to Unitarian emphasis on human capacity, in accord with Emersonian self-reliance. The notion of women's using individual skills to support themselves challenges prevailing nineteenthcentury views of the workforce, encouraging women to become vocationally productive and autonomous. And beyond her stance on employment, Fuller renounces male promiscuity and infidelity, believing that both sexes, preceding their union, commit fully to their impending marriages and remain pure. From the vantage provided by columns in the Christian Inquirer, I shall argue that Fuller's outlook, echoing many Unitarian values, apparently influenced those who subscribed to the Unitarian outlook on the suffrage movement. And while many of these newspaper reviews postdate the publication of Woman in the
Nineteenth Century, they represent, often by way of legacy, the mindsets of Unitarian men in accord with Fuller's social orientation. The values and contribution of Woman in the Nineteenth Century thus find resonance in praiseworthy columns that appeared shortly after the narrative's posthumous publication. Granted, Fuller did not influence the entire population of American Unitarians, but she still affected the views of powerful ministers and editors who either contributed or subscribed to the Christian Inquirer, a paper that lent itself to a liberally inclusive outlook on the role of women in society. As will become evident below, the newspaper columns also cast new light on Fuller's work, whose social influence we are now better able to discern via overlooked and uncollected opinions, sometimes contradictory, on the progressive woman, the expectation of purity, and the liberation of women from the home. Fuller's revolutionary opinions and writings therefore contribute to Unitarian opinion concerning the rights of women, ultimately leading to support, beyond nineteenthcentury reform, for the early twentiethcentury suffrage movement.

Important for discerning the relationship between Fuller's posthumous publications and the Unitarian church, her background lends frequent connections to Unitarian figures and influences. Though allied with the transcendentalists prior to her premature death by drowning, Sarah Margaret Fuller was born in 1810 to Timothy Fuller, a lawyer, and Margaret Crane, a devout Unitarian. In her early years, Fuller was pressured by her increasingly absent father to strive for greatness in her schooling, while also being 
required to teach her siblings (Fuller, in Fuller, Memoirs 11-13). As she attended various New England schools, she encountered renowned persons, including William Ellery Channing, the most prominent of Unitarian ministers, and Ralph Waldo Emerson, who, a Unitarian-turnedTranscendentalist, would become a lifelong friend and supporter (Clarke, in Fuller, Memoirs 62). After writing a biography of Johann Wolfgang von Goethe, Fuller came to be considered a Transcendentalist in 1837. She accepted a publishing job for The Dial, a Transcendental magazine and, during her employment, wrote "The Great Lawsuit: Man versus Men, Woman versus Women" (1843), a precursor to Woman in the Nineteenth Century. After experiencing great successes in the realms of both writing and speaking, Fuller restructured and published the 1845 treatise, Woman in the Nineteenth Century, as a book which sold out in two weeks, received great praise, but was also eventually challenged by some conservative critics. (Emerson, in Fuller, Memoirs 138-139). In 1846, Fuller traveled to Europe to become a foreign correspondent and fell in love with Giovanni Angelo, marchese d'Ossoli. Though it remains uncertain if Fuller and Ossoli ever married (he, a Catholic; she, a Protestant), they began a family and lived in Rome during the birth of the Roman Republic, which led to the family's forced return to the United States due to fear for their safety . (Fuller, in Fuller, Memoirs 290-291). Only 400 yards from New York, Fuller, her family, and her writings perished when the boat struck a sand dune. (Channing, in Fuller, Memoirs 340-341). Following her untimely death, William Ellery Channing and Ralph Waldo Emerson wrote Fuller's biography, praising her dedication to enhancing women's position in society (Emerson, in Fuller, Memoirs 138-139). Because of Fuller's liberal-Christian upbringing and association with Unitarian figures, Woman in the Nineteenth Century led several Unitarians to open their minds and hearts to the issue of female autonomy.

Comprising the core values of her treatise, Fuller's beliefs aligned with Transcendental rejection of Unitarian rationalism, as Transcendental followers sought a more spiritual connection to God. (Fuller, Woman 5-10). Moreover, in their praise of self-reliance, Transcendentalists believed that intuitive thought superseded existing - that is, historical-knowledge. In defending female capability, Fuller likewise bypassed historical precedent; and while, in certain quarters, Transcendental intuitionalism challenged the authority of Unitarian historicity, advocates from both communities shared several underlying values about the dignity of human nature. In addition to her pre-existing Unitarian beliefs, Fuller's association with Ralph Waldo Emerson, author of the foundational essay Nature, led Fuller to become fully immersed in Transcendental society and champion the status of women via homage to self-reliance. Thus, as Transcendentalism evolved from Unitarianism, Woman in the Nineteenth Century appealed to a Unitarian audience that - judging from heretofore overlooked columns in the New York Unitarian Newspaper, the Christian Inquirer-valued the work.

Even as a precursor to the Transcendentalism espoused by Fuller, Unitarianism was founded on increasingly progressive beliefs that had evolved in response to Trinitarian orthodoxy, the emphasis of which on human turpitude was everywhere conspicuous in a morphology of conversion mandating infinite atonement for infinite sin-hence, the need for a triune deity to assume varied functions in the act of efficacious grace (Channing, 7; Haroutunian, 180; Wright, 201). Still, while 
they were astoundingly progressive in comparison to the orthodox Protestants, most Unitarians did not initially offer resounding support for the women's rights movement. Focusing instead on theological beliefs that diverted from those of Calvinists, they discarded notions of the hellfire and brimstone and placed their faith in a unified conception of God that elevated the strivings and potential of human nature rather than the need for conversion and atonement. Unitarians experienced Jesus as a perfect human rather than as a deity. Hardly in need of atonement via the sacrifice of the Son, they praised the inherent dignity of human beings, thus paving the way for the Universalist elevation of all souls. (Haroutunian, 255-256; Wright, 177, 184, 194-195).

At the same time, however, as Unitarians accepted the self-worth of all people, the developed world remained, in the main, patriarchal. Traditionally, as men established themselves as both the stronger and more capable of the sexes, patriarchy defined the social roles for both men and women in nineteenth-century America. In accord with Christian values and social norms - even those practiced by the forward-thinking Unitarians - men were expected to support their families, vote in elections, and make all family decisions. Women, on the other hand were to maintain the household and raise contributive and respectful sons. Such outlook of course diminished the value of many women who stood to possess or develop skills in a profession deemed fit only for men. As stated in columns of the Christian Inquirer, the woman's primary purpose in nineteenthcentury America was to gain a husband, nurse him when he fell ill, and educate the children. ("Women" 4). As all childbearing women are remembered and praised for their duties as a mother - "Our good mothers, God bless them!” (Osgood 2)— some women prospered in their role as wife and mother, while many others yearned for additional opportunities denied to them by the patriarchy. Nor did most men transcend consensus thinking, no matter their fundamental religious beliefs, as they recommended that women "[have] a right to study the art of dress, and to avail [themselves]... of appearance" ("Beauty and Intelligence" 1) rather than study math, science, or literature, as a woman cannot "unsex herself as to take a [man's] place" ("Woman's Rights" 2).

Faced with the prospect of women's entering typically male professions, men also worried that the role of mothers and wives would be diminished, and that all women would seek to work rather than care for their households. Under a seemingly oxymoronic title of "Women's Rights," one article in the Christian Inquirer implies that it is only proper for women to prosper inside the home ("Woman's Rights" 2).

Undermining the entire basis of the women's-rights movement by implying that a woman exclusively affects only her immediate family, the writer denies women both the ability to work outside of the home and, as a correlate, the right to vote. Otherwise minded, Fuller responds to such views. In an imagined conversation between a man and a woman about the women's rights movement and its opportunities, Fuller states, "Have you asked her whether she is satisfied with these indulgences?" Fuller here refers, to the so-called leisure time afforded to women who remain in the home. What lurks beneath, however, is a sardonic reference to mandatory gifting, a Roman Catholic ritual in which sinners are granted whole or partial forgiveness of their sins by church officials. To Fuller's question, the man responds, "No, but I know she is. She is too amicable ... and too judicious to wish to step beyond the sphere of her sex" (Fuller, Woman 29). Fuller 
nonetheless argues that a woman's compliance with the will of her husband will eventually turn her sweet qualities bitter. And because men wanted to know how female equality could benefit them, Fuller suggests that a woman's gentle temperament is merely acceptance of her bleak situation rather than a reflection of her legitimate personality. By implication, men were hesitant to grant women expanded opportunities because their ignorance of women was allowing them to forgo household and parenting duties, while granting men dominance in vocational sectors.

Germane to these issues is a flowering review of Woman in the Nineteenth Century in the Christian Inquirer. Although the commentary downplayed Fuller's argument about women's roles in society, the reviewer admired Fuller's sense that "the best sphere for woman is that in which she can be the most useful" ("Woman in the Nineteenth Century" 2), a statement consistent with the paper's acceptance of women's ability to succeed in careers traditionally reserved for men, Such sentiment in a Unitarian newspaper exposed a progressive audience to the idea that women can and should be allowed to work in professions to which they are able to contribute. And even as some future contributors to the Christian Inquirer were not convinced of Fuller's argument regarding the right of women to choose their own career paths, Fuller's thesis appealed directly to the core Unitarian belief of human potential and was accepted and embraced by a portion of liberalChristian followers.

Other Unitarians concluded that women should work solely in the household, despite progressive faith in the value and potential of human life. I suggest that those men, while accepting and celebrating their own male self-reliance, did not deem women worthy of similar respect. They thus unwittingly, albeit hypocritically, negated the liberal Christian foundation of their own beliefs. Unitarians should - in accord with their religious precepts - more consistently have believed that all people are able to contribute to society in whatever manner they are most gifted. Still, as Western social and family structure is founded on patriarchy, women were deemed to be useful in their "sphere." And as is evident from those who reviewed Fuller's work in the Christian Inquirer and took issue with the then-current social expectations of women, persons who disagreed with her position may not have read Woman in the Nineteenth Century or may not have understood its implication for themselves. Anticipating such response, Fuller effectively includes man's fearful belief that their wives are dissatisfied in their meager positions of spouse and mother and yearn for increasingly fulfilling positions. Appealing therefore to the desire of men and women to establish a happy household, Fuller notes that many women hope to bear only sons, knowing the sadness that awaits women in this world (Fuller, Woman 146). She thereby appeals to men who do not want their wives to become disenchanted with their simple lives while raising a successful family. Some Unitarian men would have apprehensively entertained Fuller's conjecture because her conclusions, though disturbing, appeared compelling.

Such amicable reception is attributable, in part, to why Fuller's work appeared amid the women's suffrage movement, consistent with the principles and progressivism of the Unitarian church in its defense of human nature. Fuller's assertions clearly appealed to the Unitarian Church via compelling and enduring logic. In a review of little surprise, the newspaper praised Fuller because she "has offered a noble plea in behalf of her sex, shown the 
disabilities and injustices under which woman labors, and pointed out some of the ways of relief and redress." ("Woman in the Nineteenth Century" 2) Evident in this compliment is Unitarian respect for Fuller's work and ideals. Still, the question remains as to why they regarded her work so much more impactful than that of her feminist predecessors.

The answer resides in her inclusion of men. Unlike other women of the time, Fuller directed her argument at men and wrote her treatise concerning the thoughts of men, since "Male and female represent the two sides of the great radical dualism. They are perpetually passing into one another" (Fuller, Woman 115-116). That sentiment ensures the inclusion of the male sex in championing the importance of women. Fuller thus describes women in their relation to men rather than merely arguing, on an isolated basis, for the advancement of females. Upon realizing the failure of her earlier counterparts, Fuller discovered that, because men have already achieved freedom and authority, they are hampered in understanding pleas based solely on women's desire for autonomy.

To gain the support of men (necessary for any change to be affected in the government), Fuller strategically proposes improvements upon men's own lives that align with female independence. For instance, when describing the lack of love in romances Fuller includes examples of Shakespeare and the Commonwealth to illustrate the facts with historical accounts known to educated men of the nineteenth century. She found in every circumstance that men "could expect nothing but misery and obstruction in a domestic partnership with Woman" (Fuller, Woman 70). Through such novel devices, Fuller urged Unitarian men to support female advancement for the sake of their own future and the future of the
American household. Such was her way of grounding progressivist thought in enlightened self-interest.

Although some Unitarian men may have been persuaded of the benefits that were aligned with women's rights, many did not champion the cause for fear of having their jobs usurped by a female workforce, as can be seen in columns of the Christian Inquirer. Preceding the women's suffrage movement, very few rights were afforded to women; and due to the shifting of thought, many women yearned to work in a profession that was typically off limits. Men, in turn, while cloaking their fears under the garb of protecting women, were reluctant to alter convention. For example, one newspaper contributor reveals the actual intention of men who wish to retain their authority in certain professions: "It is ridiculous to ascribe this sentiment to the jealousy of the stronger sex. It is not from fear of competition, but from fear of losing the charm of the world; from love of woman, not from jealousy, that man so earnestly contends that she is now in her place ("The Woman's Rights Convention" 2) Use of the word "competition" concedes that women could rival the historically maledominated careers and invites a counterargument. And as if anticipating related objections in political spheres, Fuller notes that those who deem women unworthy of voting otherwise regard them as capable of undertaking prolonged and harsh work. Such is the contradiction that leads Fuller to group mainstream women with slaves and imply that both merit the franchise. They are, she implies, certainly able to vote, legislate, and lecture, and do not need the protection of the household or limited career paths. Thus, the assertion that women must remain in their current social position for their own mental and physical protection is undermined by the millions of women who have worked in demanding positions for 
many years. Utilizing the dual standard that is applied to women of different backgrounds, she supports her claim that the voting process can be no more strenuous than the everyday toil that some women endure: "Those who think the physical circumstances of woman would make a part in the affairs of the national government unsuitable, are by no means those who think it impossible for the negresses to endure field work, even during pregnancy, or the seamstress to go through their killing labors." Fuller further includes descriptive imagery of, "ludicrous pictures of ladies in hysterics at the polls, and senate chambers filled with cradles" (Fuller, Woman 29)both caricatures being male inventions that diminish the actual abilities of women. Thus, Fuller effectively evokes the labor of women in society to negate the male argument that women's "nature" should prevent them from deliberative voting.

The issue of basic rights thus led to Fuller's linking the oppression of women to that of slaves, and in such manner as to appeal to Unitarians whose elevated views of human nature inspired them to condemn human servitude. Published in the era immediately preceding the war, Woman in the Nineteenth Century utilizes, to Fuller's advantage, the tensions between the slave owners of the south and the general population of the north. As nineteenthcentury Unitarians were associated with relatively liberal views, essays concerning the abolition of slavery appeared frequently in their publications. While not consistently supporting the abolition of slavery, Unitarians more frequently called for limiting the spread of slavery, not wanting to tread the path that would eventually lead to the dissolution of the Union. As the Civil War approached, however, the Unitarians promoted the banning of slavery. Such outlook was consistent with the earlier sentiment of the Christian Inquirer that "to exclude slavery from our future territories . . . is robbing the slave states of their constitutional rights" (Cristian Inquirer 54). The writer gainsays the sentiment that limiting the spread of slavery infringes upon the rights of the current and future slave states, implying (although evasively) that much of the Unitarian church supports the anti-slavery movement. That was certainly the outlook of the Christian Inquirer, which exhaustively rebuked the pro-slavery agenda as a sin and crime. Thus, as the Confederacy grew closer to secession, Unitarians shifted from passive support of the anti-slavery movement to avid indignation. Fuller, in turn, while not directly appealing to Unitarian anti-slavery sentiment but to all of those who rejected the institution, includes the comparison of women and slaves that captivated a Unitarian audience sympathetic toward those who lack freedom. That said, the Unitarian church was willing to offer slaves constitutional rights before granting the same to women.

Years after the publication of Woman in the Nineteenth Century, a contributor to the Christian Inquirer chose to reiterate this portrayal of women as slaves: "I am in favor of her right . . . of developing and perfecting her own rich and generous nature under the genial influences of home" ("Women's Rights" 2). This man refers to white housewives - not slaves; and while it is apparent to whom he is alluding, his wish for women to remain in the household correlates directly to Fuller's argument that women's restricted freedom is comparable to that of slaves. Contesting such outlook, Fuller had stated that "the only reason why women ever assume what is more appropriate to you, is because you prevent them from being free. Were they free ... they would never wish to be men or man-like" (Fuller, Woman 63). The implication is that, once free and equal, women will grow into powerful versions of 
themselves. This argument would have appealed to men of the time who were primarily concerned that their wives and daughters retain their femininity in a harsh world. Fuller's appeal would therefore have inspired women who were seeking to experience a career beyond the household. After assessing such advantages, editors of the Christian Inquirer found her position to be appropriate and well thought out; they acknowledged that much of the opposition to Woman in the Nineteenth Century was erroneously based ("Woman in the Nineteenth Century" 2). In appreciating the contribution of Fuller, the editors, unlike their various contributors, believed that women were strong and intelligent enough to bring individual talent to jobs for which they were most suited - rather than their being reduced to household labor.

With women being restricted to the domestic sector, a discrepancy existed-one which Fuller outlines between the expected actions of men and women in marriage. Her assertion that all people should remain pure in their marital commitments further resonated with the outlooks in the Christian Inquirer, because of Unitarian belief in humanity's inherent goodness. Because women generally remained in the home once married, they had little opportunity to become unfaithful in their union and were expected to remain loyal to their husband in all circumstances. As noted in her treatise, Fuller wholly supported the idea of such loyalty but took issue with the expectation that only women were required to remain devoted. Men were not held to the same standard as women and frequently had opportunities to act upon their impulses. While wives and mothers remained at home to raise the children and execute their household duties, husbands and fathers worked outside of the household and could more easily stray. Fuller accounts for the way women, dissatisfied for lack of public life, became irritable and cold toward their husbands, causing some men to seek affection elsewhere. Because they were unable to control their instinct and passion, these men engaged in actions deemed excusable. Fuller nonetheless counters with an example of medieval romantic tradition: "Did they believe purity more impossible to man than to women ... and [that] temperate habits would not keep him free from slavery to the body?'(Fuller, Woman 134). She asserts that in times past, love was to be between one worthy man and an equally deserving woman. Though frequent, her use of comparison between the male and female sex may have influenced writers of the Christian Inquirer, as Fuller's assertions aligned with many basic Unitarian beliefs. Thus, as men do not wish to be inferior to women and as Fuller implies the impossibility of chastity to men, the newspaper's writers convince their audience that both men and women should be held to the same standard regarding purity and faithfulness: "What [Fuller] says of the law of purity being binding upon man as well as women, no young man can read without profit" ("Woman in the Nineteenth Century" 2 ). But in deflecting the severity of the topic at hand, they conclude that "young men" can gain from a reading of Woman in the Nineteenth Century, which highlights their own generation's wrongdoings. The aged Unitarian editors thus recommend Fuller's work to those in young relationships, all the while more generally praising her outlook. Fuller's thesis would appear to have found a warm reception among the Unitarians because of their belief in the merit of all people and the pertinence scripture.

As Fuller was a Transcendentalist advocate, one might have expected something less than a warm reception of her views in a Unitarian newspaper (Hutchinson, 148, 160, 175; Miller, 331332). Still, many of her outlooks pertaining 
to human nature and potential align with those of the New York Christian Inquirer. The Transcendentalists of the nineteenth century rejected their Unitarian predecessors due to the latter's dry interpretation of biblical teachings. But because Fuller's Woman in the Nineteenth Century has been shown to appeal directly to the beliefs of the Unitarians, the treatise advanced the progressive view of women that was easily comprehensible and relevant to the editors of the Christian Inquirer. Although Fuller's single narrative did not alter the perceptions of all Unitarian men and women who relied on the predetermined household structure of their parents and grandparents, it offered a prescient outlook on the freedom of women. In analyzing her argument, which advances that women should be allowed to work in accord with their talents, the Christian Inquirer states, "What they are fitted to do, fitted to do better than men, God has intended them to do, and no opposition on man's part will prevent them from doing it" ("Woman in the Nineteenth Century" 2). Therefore, as Fuller advances that women are capable of anything they wish, the Unitarians find symmetry between her beliefs and their own faith in the reasoning capacity of all people.

Fuller likely did not intend to be a major influence on the Unitarian support of the suffrage movement but aimed more generically to change the socially determined male expectation of women. That said, this particular collection of columns in the Christian Inquirer-articles written about both women in general and Margaret Fuller in particular - casts new light on the significance of Fuller's writings in affecting Unitarian perceptions and opinions in nineteenth-century, and likely beyond.

\section{Bibliography}

"Beauty and Intelligence ." Christian Inquirer , 3 Sept. 1856, p. 1.

Channing, William Ellery, 1780-1842, Nathaniel Thayer, and Eliphalet Porter. A Sermon Delivered At the Ordination of the Rev. Jared Sparks, to the Pastoral Care of the First Independent Church In Baltimore, May 5, 1819.. 7th ed. Boston: Cummings and Hilliard, 1819.

Christian Inquirer, 16 Jan. 1847, p. 54.

Fuller, M., Emerson, R. W., Channing, W. H., \& Clarke, J. F. (1881). Memoirs of Margaret Fuller Ossoli. Boston, Massachusets: Roberts Brothers.

Fuller, Margaret. Woman in the Nineteenth Century: With an Introduction. by Bernard Rosenthal. Norton, 1980.

Haroutunian, Joseph. Piety Versus Moralism . Archon Books, 1964.

Hutchison, William. The Transcendentalist Ministers. Archon Books, 1972.

Miller, Perry. The Transcendentalists: An Anthology. Harvard Univ. Press, 1971.

Osgood. "The New-England Dinner." Christian Inquirer, 3 Jan. 1857, p. 2.

"The Woman's Rights Convention ." Christian Inquirer, 2 Oct. 1850, p. 2.

"Women." Christian Inquirer, 1 Sept. 1855, p. 4.

"Woman's Rights." Christian Inquirer, 18 Oct. 1856, p. 2.

"Woman in the Nineteenth Century." Christian Inquirer, 22 Dec. 1855, p. 2. 
Wright, Conrad Edick. The Beginnings of Unitarianism in America. Starr King Press, 1955. 